\title{
KAJIAN PERAN KONSISTENSI DIRI TERHADAP PRESTASI BELAJAR MATEMATIKA
}

\author{
LEONARD \\ leonard@unindra.ac.id \\ 0813829399050 \\ Program Studi Pendidikan Matematika, Fakultas Teknik, Matematika dan IPA \\ Universitas Indraprasta PGRI
}

\begin{abstract}
Abstrak. Penelitian ini bertujuan untuk mengetahui pengaruh konsistensi diri terhadap prestasi belajar matematika di SMP 179 Jakarta. Metode yang digunakan adalah survei korelasional. Populasi penelitian ini adalah siswa kelas VIII. Sampel diambil menggunakan teknik simple random sampling, sejumlah 70 orang siswa. Instrumen yang digunakan adalah angket konsistensi diri dan tes hasil belajar matematika. Data dianalisis menggunakan korelasi dan regresi sederhana. Dari pengujian hipotesis menghasilkan kesimpulan bahwa terdapat pengaruh positif dan signifikan konsistensi diri terhadap prestasi belajar matematika.
\end{abstract}

Kata Kunci: matematika, prestasi belajar, konsistensi diri.

\begin{abstract}
The aim of this research is to know the influence of self-consistency of the student toward the learning result (achievement) in junior high scholl 179 Jakarta. The research method which was used in the research is survey method. The population of research is all students in class VIII. Samples are taken by simple random sampling, consisted of 70 students. The research instrument is a self-consistency and mathematics learning achievement. Data analyzed by simple regression techniques. The hypothesis testing resulted conclution; there positive and significant effect of self-consistency toward mathematics learning achievement.
\end{abstract}

Keywords: mathematics, achievement, self-consistency.

\section{PENDAHULUAN}

Pendidikan merupakan segala situasi hidup yang mempengaruhi pertumbuhan individu sebagai pengalaman belajar yang berlangsung dalam segala lingkungan dan sepanjang hayat. Selain itu, pendidikan sebagai indikator kemajuan bangsa dipandang penting dalam proses pembangunan. Menurut Ahmadi (2001: 98), "maju mundurnya suatu bangsa sebagian besar ditentukan oleh maju mundurnya pendidikan di negara tersebut". Untuk itulah, pemerintah selalu berusaha untuk memperbaiki sistem pendidikan di negara ini. Terbukti, negara kita sudah beberapa kali mengubah kurikulum. Hal ini dilakukan dalam rangka ingin mencerdaskan kehidupan bangsa, terlepas dari polemik masalah kurikulum yang ada.

Keberhasilan pendidikan yang ingin diciptakan pemerintah mungkin akan terkendala. Mutu pendidikan Indonesia, terutama dalam mata pelajaran matematika masih rendah. Data UNESCO menunjukkan, peringkat matematika Indonesia berada di deretan 34 dari 38 negara. Sejauh ini, Indonesia masih belum mampu lepas dari deretan penghuni papan bawah. Hasil penelitian tim Programme of International Student Assessment (PISA) 2001 menunjukkan, Indonesia menempati peringkat ke-39 dari 41 negara pada kategori literatur matematika.

Melihat bukti bahwa prestasi matematika kita masih jauh dari yang diharapkan sangat bertolak belakang dengan tujuan pendidikan. Hakikinya, dengan terlaksananya 
proses belajar, maka individu akan mendapatkan prestasi atau hasil yang ingin dicapainya. Prestasi atau hasil selalu menjadi tolak ukur keberhasilan usaha seseorang. Ali (1985: 42) mengatakan, "usaha selalu melihat kepada tujuan, hasil, dan nilai". Hal ini berarti bahwa tujuanlah yang menggerakkan usaha.

Prestasi matematika yang rendah adalah bukti masih banyak siswa yang mengalami kesulitan dalam menyelesaikan soal matematika. Padahal, matematika yang merupakan ilmu yang universal, yang mendasari perkembangan teknologi modern, mempunyai peran penting dalam berbagai disiplin dan mengembangkan daya pikir manusia. Salah satu faktor siswa mengalami kesulitan adalah kurangnya persiapan. Hal ini dikarenakan siswa tersebut tidak memiliki kesiapan untuk menghadapi matematika dalam level yang lebih tinggi. Selain itu, masih adanya sistem belajar yang menyamaratakan kemampuan siswa menjadi penyebab siswa tersebut merasa matematika itu sulit. Dari permasalahan inilah, matematika sering menjadi momok yang menakutkan. Momok inilah yang membuat nilai matematika rendah.

Kemungkinan ketidaksiapan siswa dalam menyelesaikan soal matematika, salah satu faktornya adalah karena siswa tersebut tidak memiliki konsistensi diri yang baik. Karena, pada hakikinya, setiap siswa memiliki konsistensi diri namun intensitasnya yang berbeda. Konsistensi diri adalah ketetapan hati akan prinsip yang telah ditetapkan oleh dirinya sendiri. Konsistensi diri juga berarti bahwa seseorang menjalankan apa yang telah ia ucapkan, atau dapat juga dikatakan melakukan suatu hal yang serupa dalam dan kondisi yang hampir sama.

Siswa yang memiliki tingkat konsistensi yang rendah, biasanya memiliki prestasi yang rendah pula. Khalsa (2008: 64) mengatakan "siswa yang berprestasi lebih rendah daripada seharusnya atau yang memperlihatkan perilaku negatif di kelas biasanya mempunyai pengalaman bertahun-tahun konsep diri yang hancur". Konsep diri berkaitan erat dengan prinsip yang diambil. Seseorang yang memegang teguh prinsip tergolong orang yang memiliki konsistensi diri. Hal ini berarti bahwa orang tersebut telah memiliki konsep diri yang baik. Salah satu konsep diri yang baik adalah menerapkan sikap disiplin di dalam hidupnya. Sulastri (2007: 17) mengemukakan, "disiplin adalah segala tindakan yang dilakukan secara efektifitas dan efisien oleh seseorang untuk mencapai tujuan". Dengan adanya sikap disiplin, maka seseorang dapat mencapai tujuannya secara lebih efektif.

Disiplin berarti mengerjakan sesuatu sesuai jadwal yang telah ditentukan. Hal ini berarti, disiplin mengarahkan kita secara sadar untuk bertindak sesuai dengan peraturan yang ada. Hal ini senada dengan Hasibuan (Sulastri, 2007: 17), "kedisiplinan adalah kesadaran dan kesediaan seseorang menaati semua peraturan perusahaan dan normanorma sosial yang berlaku". Disiplin dapat membantu seseorang untuk memiliki sikap konsistensi diri yang baik. Dengan adanya disiplin diri, seseorang secara sadar dan tanpa paksaan menjalankan aturan dan rancangan yang berlaku demi tercapainya tujuan hidup yang diinginkan.

Kenyataannya, tidak mudah menerapkan sikap disiplin pada anak. Anak cenderung malas bahkan menolak ketika disuruh belajar. Malas belajar adalah suatu sikap yang mencerminkan seseorang tidak memiliki disiplin belajar. Hal ini dapat terjadi bila anak tidak memiliki jam belajar yang tepat. Akibatnya, prestasi belajarnya akan menurun. Dengan demikian, siswa yang memiliki konsistensi diri yang baik kemungkinan besar prestasi belajar siswa dalam pembelajaran matematika pun akan baik pula. Hal tersebut dapat dicapai, salah satunya dengan menerapkan disiplin belajar yang baik. 


\section{TINJAUAN PUSTAKA}

\section{Konsistensi Diri}

Diri itu merupakan salah satu aspek dari kepribadian. Hal ini diungkapkan Mahmud (2010: 365), "diri itu berasal dari kata self, merupakan salah satu aspek sekaligus inti kepribadian seseorang yang didalamnya meliputi segala kepercayaan, sikap, perasaan, dan cita-cita". Hal ini berarti seseorang dapat dikenali berdasarkan kepribadian dan tindakan yang diambil. Dalam bertindak, diri tak pernah lepas dari individu dan lingkungan sekitar. Menurut Ahiri (2007: 2), "diri (self) sebagai produk dari interaksi sosial berkembang dari hubungan antar pribadi dan cenderung konsisten". Jadi, seseorang dalam hidupnya pasti akan mengalami proses interaksi dengan orang lain.

Sikap konsistensi seseorang berpengaruh terhadap perilaku yang dia lakukan. Hal ini senada dengan Gea (2006: 25), "konsisten dapat dimengerti sebagai kesesuaian antara perkataan dan tindakan". Senada dengan Gea, Robbins (2010: 41), "konsistensi berarti setiap individu berusaha untuk menyelaraskan sikap dan perilaku agar terlihat rasional dan konsisten". Hal ini berarti bahwa seseorang yang konsisten berarti memiliki sikap tetap, selalu berusaha menyelaraskan perkataan, sikap dan perilakunya.

Konsistensi adalah suatu hal yang kita yakini secara prinsip dan terus menerus kita lakukan. Seperti yang dikemukakan Evertson (2011: 184), "konsistensi berarti mempertahankan ekspektasi yang sama bagi perilaku yang pantas dalam sebuah kegiatan tertentu sepanjang waktu dan bagi seluruh siswa". Jelaslah bahwa orang yang konsisten tidak terpengaruh oleh perubahan di luar dirinya.

Seseorang yang memiliki konsistensi diri tidak akan mudah terpengaruh dengan informasi baru. Ia akan tetap seperti apa yang diyakininya. Seperti yang dikemukakan Besten (2010: 120), "ketetapan hati (konsistensi diri) adalah keteguhan akan tujuan, kehendak, dan minat". Senada dengan Besten, Sonia mengungkapkan, "konsistensi diri adalah bersikap tetap, berpegang teguh, sesuai dengan apa yang telah ditekadkan terhadap diri kita sendiri".

Keteguhan dalam menetapi prinsip merupakan salah satu perilaku seseorang yang memiliki sikap konsistensi. Hal ini sesuai dengan Sonia, "perilaku konsistensi diri salah satunya dapat terlihat pada tepatnya seseorang dalam berpikir, tutur bahasa tegas dalam berbicara, konkret dalam bertindak, teguh dalam berprinsip, serta pastinya bersifat korektif'. Jadi, seseorang yang konsisten akan bersikap teguh terhadap prinsip, selalu berusaha untuk mewujudkan tujuannya serta hati-hati dalam bertindak.

Seseorang yang memiliki minat dan tujuan tertentu tidak akan berhasil apabila tidak memiliki sikap konsistensi. Seperti yang dikemukakan Asyiqor (2005: 178), "suatu keinginan tidak akan terarah pada suatu perbuatan dalam mewujudkan niatnya selama tidak mempunyai ketetapan hati yang kuat dan tidak ada keraguan”. Senada pula dengan Darmiko (Kompasiana, 2011), "karya hanya tercipta dari konsistensi diri. Semua pencapaian hasil yang disebut keberhasilan hanya dapat tercipta lewat konsistensi diri". Jelaslah bahwa konsistensi diri diperlukan seseorang untuk mencapai kehendak, karya, dan tujuannya.

Melakukan sesuatu secara konsisten menjadi sesuatu yang sangat penting dalam hidup. Konsistensi adalah sebuah usaha untuk terus dan terus melakukan sesuatu sampai pada tercapai tujuan akhir. Untuk bisa memiliki konsistensi diri, seseorang harus bisa menjaga irama hati. Nashori (2011: 175) mengemukakan, "konsistensi diri adalah kemampuan untuk menjaga irama hati dan perilaku kita sehingga kita mampu secara terus menerus memberi perhatian terhadap apa yang kita yakini sebagai sesuatu yang berharga". 
Berdasarkan pengertian-pengertian di atas, dapat disimpulkan bahwa konsistensi diri adalah sikap seseorang yang tetap, selaras, sesuai, dan teguh memegang prinsip yang diyakini untuk mencapai kehendak, minat, serta tujuan yang diinginkan.

\section{Prestasi Belajar Matematika}

Belajar adalah sebuah proses perubahan di dalam kepribadian manusia dan perubahan tersebut tercermin melalui peningkatan kualitas dan kuantitas tingkah laku. Hal ini sesuai dengan yang dikemukakan oleh Gagne (Dahar, 2006: 2), yaitu "belajar adalah suatu proses dimana suatu organisasi berubah perilakunya sebagai akibat pengalaman".

Senada dengan Gagne (Leonard \& Kusumaningsih, 2009: 85), "belajar adalah kegiatan yang berhubungan dengan perubahan tingkah laku manusia, yang diakibatkan oleh pengalaman". Dengan kata lain, belajar merupakan proses yang mengakibatkan perubahan setelah aktifitas yang dilakukan oleh siswa, yaitu proses pembelajaran. Slameto (2003: 8) mengatakan, "belajar adalah suatu proses usaha yang dilakukan oleh individu untuk memperoleh perubahan tingkah laku yang baru secara keseluruhan, sebagai hasil pengamatan individu itu sendiri dalam interaksinya dengan lingkungannya".

Istilah matematika itu sendiri berasal bebagai macam kata. Menurut Nasoetion (1982: 12), "berdasarkan kata Yunani, matematika yaitu "mathein" atau "manthenein", yang berarti mempelajari. Selain itu, matematika juga berasal dari bahasa sansekerta yaitu "medha" atau "widya", yang berarti kepandaian, ketahuan, dan intelegensi". Ini berarti bahwa dalam mempelajari matematika diperlukan pemikiran yang logis.

Matematika juga bisa berbentuk konsep. Djati (2002: 158), mengemukakan, "matematika adalah pengkajian logis mengenai bentuk, susunan, besaran, dan konsepkonsep yang berkaitan; matematika seringkali dikelompokkan ke dalam tiga bidang: aljabar, analisis, dan geometri, walaupun demikian tidak dapat dibuat pembagian yang jelas karena cabang-cabang ini telah bercampur-baur".

Dalam proses belajar mengajar, pendidik ingin meningkatkan potensi siswa, salah satunya pada mata pelajaran matematika. Adams (Wijaya, 2012: 5) berpendapat, "cara dan pendekatan dalam pembelajaran matematika sangat dipengaruhi oleh pandangan guru terhadap matematika dan siswa dalam pembelajaran". Tujuan pembelajaran yang lainnya adalah adanya perubahan perilaku. Hal ini senada dengan Siregar (2010: 5), "seseorang telah belajar bila telah terdapat perubahan tingkah laku dalam dirinya". Jadi, perubahan perilaku siswa merupakan hasil proses belajar. Hasil yang dicapai siswa setelah melakukan proses belajar dinamakan prestasi. Prestasi merupakan kecakapan atau hasil kongkret yang dapat dicapai pada saat atau periode tertentu. Dapat dikatakan bahwa prestasi adalah hasil yang telah dicapai siswa dalam proses pembelajaran. Hal ini senada dengan Gibson (1985: 52), "prestasi adalah hasil yang diharapkan".

Pada dasarnya, prestasi belajar merupakan kemampuan internal yang diperoleh sesuai dengan tujuan pembelajaran, walaupun ada juga yang diperoleh dari faktor eksternal. Hal ini senada dengan Supardi (2011), "kemampuan dasar dipengaruhi oleh dua, yaitu eksternal dan internal. Sedangkan menurut Gibson (1985: 64), "kemampuan adalah sifat yang dibawa lahir atau dipelajari yang memungkinkan seseorang menyelesaikan pekerjaannya".

Prestasi belajar dibedakan menjadi tiga aspek. Hal ini sesuai dengan yang dikemukakan oleh Arikunto (1990: 110), "hasil belajar dibedakan menjadi tiga aspek, yaitu kognitif, afektif, dan psikomotorik". Apabila tiga aspek di atas tersebut terpenuhi, maka prestasi belajar dikatakan sempurna. Jadi, prestasi belajar merupakan hal yang tidak bisa dipisahkan dari kegiatan belajar sebab kegiatannya merupakan proses dan dari proses itulah tercipta prestasi. 
Jadi, dapat disimpulkan bahwa prestasi belajar matematika yaitu skor tentang kemampuan atau tingkat penguasaan materi pelajaran berupa konsep matematika yang diperoleh siswa selama proses belajar mengajar dan mampu memecahkan masalah matematika sesuai dengan tujuan pembelajaran matematika.

\section{METODE}

Penelitian dilaksanakan di Sekolah Menengah Pertama di jalan Kalisari, Pasar Rebo, Jakarta Timur. Tepatnya di SMP 179 Jakarta. Pelaksanaan penelitian dilaksanakan dalam waktu empat bulan pada tahun 2013.

Metode yang digunakan dalam penelitian ini adalah metode survei dengan teknik analisis regresi sederhana. Populasi dalam penelitian ini adalah siswa-siswi SMP 179 Jakarta kelas VIII. Sampel diambil dari populasi terjangkau dengan teknik simple random sampling. Dalam penelitian ini, jumlah popolasi siswa SMP 179 kelas VIII sebanyak 315 siswa dan sampel yang digunakan sebanyak 70 siswa.

Pengumpulan data untuk variabel prestasi belajar matematika diperoleh dari hasil tes ulangan tengah semester yang diberikan kepada siswa dan datanya diperoleh dari guru mata pelajaran. Sedangkan untuk variabel konsistensi diri melakukan tes tertulis berupa angket skala likert, masing-masing sebanyak 27 pernyataan.

\section{HASIL DAN PEMBAHASAN \\ Data Prestasi Belajar Matematika}

Dari hasil pengukuran prestasi belajar matematika terhadap 70 siswa yang dijadikan sampel penelitian, diperoleh data skor maksimum 100 dan skor minimum 60, sehingga diperoleh rentang (jangkauan) data sebesar 40. Berdasarkan hasil analisis data, diperoleh mean 87,3; median 90,05; modus 93,17; dan simpangan baku 8,48. Dengan demikian, dapat dikatakan bahwa prestasi belajar matematika siswa tergolong baik.

\section{Data Konsistensi Diri}

Dari hasil pengukuran konsistensi diri terhadap 70 siswa yang dijadikan sampel penelitian, diperoleh data skor maksimum 125 dan skor minimum 71, sehingga diperoleh rentang (jangkauan) data sebesar 54. Berdasarkan hasil analisis data, diperoleh mean 98; median 99,3; modus 105,27; dan simpangan baku 9,41. Dengan demikian, dapat dikatakan bahwa konsistensi diri siswa tergolong baik.

\section{Uji Persyaratan Analisis Data}

Data yang telah dikumpulkan selanjutnya diuji persyaratan analisis, yang meliputi uji normalitas dan uji linearitas. Hasil pengujian normalitas menggunakan uji liliefors diperoleh hasil bahwa seluruh variabel berdistribusi normal. Hasil pengujian linearitas diperoleh hasil bahwa $\mathrm{X}_{1}$ dan $\mathrm{Y}$ berpola linear.

\section{Pengujian Hipotesis Penelitian}

Untuk mengetahui tingkat keeratan hubungan antara variabel $\mathrm{X}_{1}$ terhadap variabel Y dalam penelitian ini digunakan teknik korelasi dan regresi sederhana. Hasil perhitungan korelasi diperoleh nilai 0,86 yang artinya terdapat hubungan sangat kuat antara konsistensi diri dengan prestasi belajar matematika. Nilai koefisien determinasi diperoleh sebesar $74,55 \%$. Artinya, kontribusi konsistensi diri terhadap prestasi belajar matematika sebesar $74,55 \%$ dan sisanya dipengaruhi faktor lain yang tidak dibahas dalam penelitian ini.

Persamaan regresi sederhana yang terbentuk adalah $\hat{Y}=11,36+0,78 \mathrm{X} . \quad$ Untuk pengujian keberartian koefisien regresi dilakukan dengan uji F untuk taraf nyata $\alpha=5 \%$, 
$\mathrm{dk}$ pembilang $=1$, dk penyebut $=68$, diperoleh $\mathrm{F}_{\text {tabel }}=3,96$ dan $\mathrm{F}_{\text {hitung }}=199,21$. Karena $\mathrm{F}_{\text {hitung }}>\mathrm{F}_{\text {tabel }}$, maka $\mathrm{H}_{0}$ ditolak dan $\mathrm{H}_{1}$ diterima, yang berarti koefisien regresi sederhana yang terbentuk dari konsistensi diri terhadap prestasi belajar matematika adalah signifikan.

\section{Pembahasan}

Berdasarkan hasil penelitian dan hasil pengujian hipotesis, maka terbukti bahwa terdapat pengaruh positif konsistensi diri terhadap prestasi belajar matematika. Hal ini berarti bahwa prestasi belajar matematika akan semakin baik apabila konsistensi diri ditingkatkan. Berdasarkan fakta tersebut dapat dikatakan bahwa sebenarnya untuk meningkatkan prestasi belajar matematika harus terlebih dahulu meningkatkan konsistensi diri.

Penelitian Resya (2012), yang berjudul "pengaruh konsistensi diri terhadap prestasi belajar matematika" menemukan bahwa pada kelompok siswa yang memiliki konsistensi diri tinggi memberikan prestasi belajar yang tinggi pula. Sebaliknya, kelompok siswa yang memiliki konsistensi diri rendah memberikan prestasi belajar yang rendah pula. Hal ini membuktikan bahwa prestasi belajar matematika tergantung dari konsistensi diri siswa, artinya besar atau kecil tingkat konsistensi diri siswa, secara signifikan meningkatkan prestasi belajar matematika, atau dengan kata lain, prestasi belajar matematika tinggi.

Konsistensi diri penting diterapkan oleh siswa karena dapat membantu siswa dalam memiliki persiapan yang baik tentang matematika. Konsistensi diri berarti kemampuan untuk menjaga irama hati agar perilaku dan ucapan kita selaras. Hal ini senada dengan Nashori (2011: 175) yang mengemukakan, "konsistensi diri adalah kemampuan untuk menjaga irama hati dan perilaku kita sehingga kita mampu secara terus menerus memberi perhatian terhadap apa yang kita yakini sebagai sesuatu yang berharga". Pengertian tersebut mempunyai arti bahwa kita dapat dikatakan konsisten apabila ucapan dan tindakan kita sesuai.

Seseorang yang memiliki minat dan tujuan tertentu tidak akan berhasil apabila tidak memiliki sikap konsistensi. Seperti yang dikemukakan Asyiqor (2005: 178), "suatu keinginan tidak akan terarah pada suatu perbuatan dalam mewujudkan niatnya selama tidak mempunyai ketetapan hati yang kuat dan tidak ada keraguan”. Senada pula dengan Darmiko (Kompasiana, 2011), "karya hanya tercipta dari konsistensi diri. Semua pencapaian hasil yang disebut keberhasilan hanya dapat tercipta lewat konsistensi diri". Jelaslah bahwa konsistensi diri diperlukan seseorang untuk mencapai kehendak, karya, dan tujuannya.

Dalam menerapkan sikap konsistensi pada siswa memang tidaklah mudah. Semua harus diterapkan secara bertahap, perlu adanya niat yang kuat dalam hati. Salah satunya adalah dengan menerapkan sikap disiplin dalam dirinya. Hans (2006: 107), "Disiplin adalah kemampuan untuk melakukan apa yang seharusnya dilakukan, ketika kita harus melakukannya entah kita suka melakukannya atau tidak". Hal tersebut berarti bahwa sikap disiplin menuntut kita untuk patuh terhadap peraturan. Hal ini berkaitan dengan prinsip dasar sikap orang yang konsisten, yaitu menetapi apa yang sudah ditetapkan oleh dirinya sendiri, atau dengan kata lain "memegang prinsip".

Seseorang yang memiliki sikap konsistensi akan memiliki sikap disiplin yang baik karena disiplin merupakan salah satu aspek penting dalam diri seseorang yang konsisten. Jadi, disiplin yang baik dapat membantu seseorang dalam meningkatkan konsistensi diri.

Memang tidak mudah untuk menanamkan sikap disiplin pada anak. Perlu latihan secara intensif dan harus dilakukan sejak dini agar sikap disiplin dapat terpatri di dalam diri anak sehingga anak sadar akan peraturan dan selalu membutuhkan sikap disiplin 
dalam hidupnya. Maka dalam penelitian ini, guru matematika harus dapat membantu siswa dalam menerapkan sikap konsistensi diri ketika proses kegiatan belajar mengajar sedang berlangsung. Guru dapat memberi tugas kepada siswa yang waktu pengumpulannya harus tepat waktu atau menerapkan aturan-aturan lain yang dapat meningkatkan sikap disiplin pada siswa.

Dengan demikian, dapat disimpulkan bahwa konsistensi diri dapat ditingkatkan dengan cara menanamkan sikap sadar terhadap disiplin dalam hidup seseorang. Seseorang yang memiliki sikap konsistensi diri, ditandai dengan adanya disiplin belajar yang baik, sehingga prestasi belajar matematikanya akan meningkat. Dengan kata lain, dampak dari sikap konsistensi diri dan disiplin belajar adalah meningkatnya prestasi belajar matematika.

\section{PENUTUP}

\section{Kesimpulan}

Berdasarkan hasil analisis dan pengujian hipotesis di atas menunjukkan bahwa terdapat pengaruh yang positif dan signifikan antara konsistensi diri terhadap prestasi belajar matematika. Dengan semakin tinggi konsistensi diri maka semakin tinggi pula prestasi belajar matematika siswa kelas VIII SMP 179 Jakarta.

\section{Saran}

Berdasarkan hasil penelitian ini, maka saran dan harapan yang bisa peneliti sampaikan yaitu guru dapat lebih mengembangkan profesionalitasnya dalam mengajar sehingga dapat membantu siswa dalam rangka mengembangkan konsistensi diri, yang nantinya siswa dapat taat dan patuh terhadap aturan yang telah ditetapkan baik oleh dirinya sendiri maupun oleh organisasi yang ada.

\section{DAFTAR PUSTAKA}

Ahiri, J. 2007. Hubungan gaya kepemimpinan dan konsep diri dengan akuntabilitas kepsek. Gema Pendidikan, 14 (2). 1-4.

Ahmadi, A. 2001. Ilmu Pendidikan. Jakarta: Rineka Cipta.

Ali, M.N. 1985. Dasar-Dasar Ilmu Mendidik. Jakarta: Mutiara Sumber Widya.

Arikunto, S. 1990. Prosedur Penelitian Suatu Pendekatan Praktik. Yogyakarta: Rineka Cipta.

Asyiqor. 2005. Fiqih Niat. Jakarta: Gema Insani Press.

Besten, K. 2010. Shine: 5 Prinsip Untuk Membuat Usaha Dan Karir Anda Melejit. Jakarta: PT. Gunung Mulia.

Dahar, R.W. 2006. Teori-Teori Belajar Dan Pembelajaran. Jakarta: Erlangga.

Darmiko, R. 2011. Konsistensi Diri. Diakses April 10. 2013 dari http://filsafat.kompasiana.com/2011/08/07/konsistensi-diri-386976.html

Djati, K. 2002. Kamus Matematika. Jakarta: Balai Pustaka.

Evertson, dkk. 2011. Manajemen Kelas Untuk Guru Sd. Jakarta: Kencana.

Gea, A.A. 2006. Integritas diri: keunggulan pribadi tangguh. Character Building Journal, 3 (1): 16-26. Diunduh April 16. 2013 dari http://eprints.binus.ac.id/ 12758/1/02_ntonius_Artikel\%201\%20Integitas\%20Diri.pdf

Gibson, J.L. 1985. Organisasi. Jakarta: Erlangga.

Hans, J.Z.A. 2006. Strategi Pengembangan Diri. Jakarta: Personal Development Training.

Khalsa, S. 2008. Pengajaran Dan Disiplin Harga Diri. Jakarta: PT. Indeks. 
Leonard \& Kusumaningsih, K.D. 2009. Pengaruh model pembelajaran kooperatif tipe Team Games Tournament (TGT) terhadap peningkatan hasil belajar biologi pada konsep sistem pencernaan manusia. Jurnal Formatif, 2 (1): 83-98.

Mahmud. 2010. Psikologi Pendidikan. Bandung: Pustaka Setia.

Nashori, F. 2011. Agar Anak Anda Berprestasi. Yogyakarta: Pustaka Zeedny.

Nasoetion, A.H. 1982. Landasan Matematika. Jakarta: Bhratara Karya Aksara.

Resya, K.N.P. 2012. Pengaruh Konsistensi Diri Siswa Terhadap Prestasi Belajar Matematika. Jakarta: Skripsi Fakultas Teknik, Matematika, dan Ilmu Pengetahuan Alam Universitas Indraprasta PGRI. Tidak Dipublikasikan.

Robbins, S.P. 2010. Manajemen. Jakarta: Erlangga.

Siregar, E dan Nara, H. 2010. Teori Belajar Dan Pembelajaran. Bogor: Ghalia Indonesia.

Slameto. 2003. Belajar Dan Faktor-Faktor Yang Mempengaruhinya. Jakarta: Rineka Cipta.

Sonia. 2012. Membentuk Konsistensi Diri. Diakses April 12. 2013 dari http://soniahosey05.blogspot.com/2012/10/membentuk-konsistensi-diri-by-soniahr.html

Sulastri, T. 2007. Hubungan motivasi berprestasi dan disiplin dengan kinerja kerja dosen. Jurnal Optimal, 1 (1): 13-21. Diunduh April 21. 2013 dari http://www.ejournal-unisma.net/ojs/index.php/optimal/article/download/417/390

Supardi. 2011. Intensitas penilaian formatif dalam pembelajaran kalkulus dengan mengendalikan kemampuan awal mahasiswa. Jurnal Formatif, 1 (1): 1-9.

Wijaya, A. 2012. Pendidikan Matematika Realistik. Yogyakarta: Graha Ilmu.

http://www.topix.com/forum/world/malaysia/TPKMP1F380BEBFJGS). Diakses April 10. 2013. 